\title{
OPTIMALISASI FUNGSI MANAJEMEN DALAM PEMBELAJARAN
}

\author{
Saprin \\ Fakultas Tarbiyah dan Keguruan UIN Alauddin Makassar \\ Kampus II: Jalan Sultan Alauddin Nomor 36 Samata-Gowa \\ Email: saprinsagena@yahoo.com
}

\begin{abstract}
Abstrak
Manajemen yang dipandang sebagai suatu proses atau kerangka kerja yang melibatkan bimbingan atau pengarahan suatu kelompok orang-orang ke arah tujuantujuan organisasi atau maksud-maksud yang nyata. Substansi yang menjadi garapan manajemen dalam penyelenggaraan proses pembelajaran di sekolah adalah perencanaan, pengorganisasian, penggerakan, dan pengawasan. Efektivitas penerapan fungsi-fungsi manajemen dalam kegiatan pembelajaran diindikasikan dengan aplikasi prinsip-prinsip perencanaan pembelajaran, penerapan fungsi pengorganisasian dalam kegiatan pembelajaran, Penerapan fungsi penggerakan dalam pembelajaran, dan Penerapan fungsi pengawasan dalam kegiatan pembelajaran.
\end{abstract}

\begin{abstract}
:
Management is seen as a process or framework that involves guidance or direction of a group of people toward the organizational goals or real purposes. The substances that become management studies in the process of instructional implementation at school are planning, organization, actuation, and supervision. The effectiveness of the application of management function in instructional activity is indicated by the application of lesson plan principles, implementing organizational actuating, and supervision functions in instructional activities.
\end{abstract}

Kata kunci:

Manajemen, pembelajaran, pendidikan.

KONSEP manajemen mencakup kegiatan untuk mencapai tujuan, dilakukan oleh individu-individu yang menyumbangkan upayanya yang terbaik melalui tindakan-tindakan yang telah ditetapkan sebelumnya. Hal tersebut meliputi pengetahuan tentang apa yang harus dilakukan, menetapkan cara melakukannya, memahami bagaimana harus melakukannya, dan mengukur efektivitas dari usaha-usaha yang telah dilakukan. ${ }^{1}$

Manajemen merupakan suatu kegiatan yang kompleks, mencakup pengetahuan tentang kegiatan yang dituangkan dalam suatu perencanaan, menetapkan cara melakukan suatu kegiatan yang dimanifestasikan dalam bentuk pelaksanaan, dan mengukur efektivitas usaha yang dilakukan dengan mengevaluasi seluruh aktivitas dalam pencapaian tujuan.

Manajemen merupakan suatu kegiatan yang seluruhnya bersifat manajerial, pelaksanaannya disebut manajing dan orang yang melakukannya disebut manajer, ${ }^{2}$ sedangkan ilmu yang bersangkut paut dengannya disebut manajemen. Dengan demikian, manajemen merupakan suatu ilmu yang membahas tentang manajerial, mana- 
jing, dan manajer. Inti pokok dalam manajemen adalah usaha-usaha secara kooperatif. Artinya, tugas-tugas operasional dilaksanakan dengan baik oleh setiap anggota dalam kelompok.

Manajemen sebagai suatu ilmu dan teknik untuk mengurus atau mengelola, tidak terlepas dari fungsi-fungsi dan kewajiban manusia, baik mengenai hubungan manusia dengan Khaliknya, hubungan manusia dengan sesama manusia, maupun hubungan manusia dengan makhluk lain.

Islam meletakkan dasar yang kuat mengenai hubungan-hubungan tersebut dengan ajaran tauhid yang mengatur hubungan antara manusia dengan Khaliknya, ajaran tentang akhlak yang mengatur hubungan manusia dengan sesama manusia dan makhluk lainnya, serta ajaran tentang syariat yang mengatur hubungan muamalah. Manajemen dengan fungsi-fungsi, unsur-unsur, kegiatan-kegiatan, dan prosesnya, menempatkan manusia sebagai postulat dan fokusnya, tidaklah dapat dilepaskan dari hukum Islam. ${ }^{3}$

Ajaran Islam yang menetapkan masalah manajemen ini ke dalam fungsi dan kewajiban manusia, baik sebagai hamba Allah (abdu al-Allah) yang patuh dan taat menjalankan perintah Allah dan menghindari larangan Allah secara ikhlas dan konsisten, maupun sebagai khalifah Allah di muka bumi (khalifatu al-Allah fi al-ardhi) yang diberikan kebebasan untuk memilih, berupaya dan berperan di dunia untuk meningkatkan kesejahteraan umat dan memanfaatkan serta memelihara kelestarian dunia. ${ }^{4}$ Di dalam mengemban kedua fungsi di atas, sehingga pembelajaran berbasis manajemen merupakan fungsi manajer di sekolah yang bertujuan untuk meningkatkan efektivitas pembelajaran.

Kepala sekolah merupakan manajer tingkat satuan pendidikan, sedangkan guru merupakan manajer kelas di sekolah. Penerapan manajemen pembelajaran sangat ditentukan oleh peran dan fungsi kepala sekolah dan guru dalam menyelengarakan proses pembelajaran di sekolah.

Penerapan manajemen pembelajaran yang seyogyanya mengantar peserta didik mencapai hasil belajar yang memadai, namun dalam realitas masih dijumpai adanya manajer di sekolah yang belum menerapkan manajemen pembelajaran dengan optimal, sehingga mempengaruhi rendahnya hasil belajar peserta didik. Dalam kaitan ini, penerapan manajemen pembelajaran dipandang berkorelasi secara signifikan dengan hasil belajar peserta didik.

\section{BELAJAR DAN PEMBELAJARAN}

Belajar sebagai bagian dari pembelajaran, telah diatur dalam Undang-undang Republik Indonesia Nomor 20 Tahun 2003 tentang Sistem Pendidikan Nasional, bahwa pembelajaran adalah proses interaksi peserta didik dengan pendidik dan sumber belajar pada suatu lingkungan belajar. ${ }^{5}$ Karena itu, belajar merupakan suatu rangkaian antara proses dan hasil. Hasil belajar siswa dapat ditunjukkan dalam suatu proses pembelajaran. Proses dan hasil belajar tersebut hanya dapat dipahami secara mendalam melalui kajian tentang makna belajar itu sendiri. 
Pembelajaran mengandung unsur-unsur penting, yaitu peserta didik atau siswa, pendidik atau guru, sumber belajar, dan lingkungan belajar. Unsur-unsur tersebut mencakup unsur manusia dan unsur nonmanusia. Unsur manusia mencakup peserta didik dan pendidik, sedangkan unsur selain manusia berupa sumber belajar dan lingkungan belajar. Antara peserta didik dengan pendidik berinteraksi dalam suatu lingkungan belajar dengan memanfaatkan sumber belajar yang tersedia.

Pembelajaran merupakan suatu proses yang berlangsung dalam kegiatan belajar siswa dan kegiatan mengajar guru, sehingga proses pembelajaran akan senantiasa merupakan proses kegiatan interaksi antara dua unsur manusiawi, yakni siswa sebagai pihak yang belajar dan guru sebagai pihak yang mengajar, dengan siswa sebagai subjek pokoknya. ${ }^{6}$ Dalam proses interaksi antara siswa dan guru, dibutuhkan komponen-komponen pendukung seperti adanya tujuan yang ingin dicapai, bahan atau pesan yang menjadi isi interaksi, pelajar yang aktif mengalami, guru yang melaksanakan, metode untuk mencapai tujuan, situasi yang memungkinkan proses pembelajaran berjalan dengan baik, serta adanya penilaian terhadap hasil belajar.

Belajar dipandang pula sebagai suatu proses aktifitas psikis atau mental yang berlangsung dalam interaksi aktif dengan lingkungan yang menghasilkan perubahanperubahan atas pengetahuan, pemahaman, keterampilan, dan nilai atau sikap yang bersifat relatif konstan dan berbekas. ${ }^{7}$ Melalui kegiatan belajar, siswa diharapkan mengalami perubahan tentang pengetahuan, sikap, dan keterampilan sebagai akibat dari proses interaksinya secara aktif dengan lingkungan. Perubahan-perubahan yang diharapkan dialami oleh siswa dalam kegiatan belajarnya adalah perubahan dalam arti yang tetap dan berbekas.

Slameto memandang belajar sebagai suatu proses usaha yang dilakukan seseorang untuk memperoleh suatu perubahan tingkah laku yang baru secara keseluruhan sebagai hasil pengalamannya sendiri dalam berinteraksi dengan lingkungannya. ${ }^{8}$ Oleh karena itu, lingkungan sebagai sumber pengalaman belajar siswa merupakan faktor penting dalam suatu proses belajar siswa, sehingga menciptakan lingkungan yang bersifat edukatif merupakan faktor pendorong bagi siswa dalam melakukan usaha untuk memperoleh perubahan tingkah laku yang bersifat menyeluruh.

Perubahan tingkah laku yang diharapkan melalui perbuatan belajar dapat bersifat intensional, positif-aktif, dan efektif-fungsional. Intensional berarti perubahan tingkah laku itu terjadi karena pengalaman atau praktek yang dilakukannya dengan sengaja dan disadari atau bukan karena kebetulan. Positif berarti perubahan tingkah laku itu bermanfaat sesuai harapan yang lebih baik dari tingkah laku sebelumnya dan aktif berarti perubahan tingkah laku itu karena adanya usaha, efektif berarti perubahan tingkah laku itu membawa manfaat, serta fungsional berarti perubahan tingkah laku tersebut relatif tetap dan dapat direproduksi kembali setiap kali dibutuhkan. ${ }^{9}$ Perubahan-perubahan tingkah laku sebagai hasil dari suatu proses belajar di atas tidak terlepas dari peristiwa belajar itu sendiri sebagi alat untuk mencapai tujuan 
pembelajaran yang secara umum dapat dilihat pada bentuk perubahan tingkah laku yang bersifat intensional, positif dan aktif, serta efektif dan fungsional.

Agar makna perbuatan belajar lebih jelas, maka bentuk perbuatan belajar dapat dilihat dari segi proses dan dapat pula dilihat dari segi hasil. Dilihat dari segi proses, maka bentuk perbuatan belajar dibedakan atas; (1) belajar signal, yaitu memberi reaksi terhadap perangsang, (2) belajar mereaksi perangsang melalui penguatan, (3) belajar membentuk rangkaian, (4) belajar asosiasi verbal, (5) belajar membedakan hal majemuk, (6) belajar konsep, (7) belajar kaidah atau belajar prinsip, dan (8) belajar memecahkan masalah. ${ }^{10}$

Belajar signal merupakan bentuk perbuatan belajar yang paling sederhana, karena siswa atau pelajar hanya memberikan reaksi terhadap perangsang. Agar proses belajar dapat terjadi, maka diperlukan stimulus yang dapat merangsang siswa untuk belajar.

Belajar mereaksi perangsang melalui penguatan, yaitu memberikan reaksi yang berulang-ulang manakala terjadi penguatan. Penguatan dapat dilakukan oleh guru dalam proses pembelajaran melalui acungan jempol, mimik wajah yang senang, tepukan tangan, sentuhan kasih sayang, atau bentuk lain yang dapat digunakan sebagai penguatan dalam proses pembelajaran.

Belajar membentuk rangkaian, yaitu belajar menghubung-hubungkan gejala atau faktor yang satu dengan yang lain sehingga menjadi satu kesatuan atau rangkaian yang berarti. Bentuk perbuatan belajar ini dapat ditunjukkan oleh guru dalam bentuk menyusun materi sesuai urutan yang benar. Sebagai contoh, guru Pendidikan Agama Islam menyuruh siswa menyusun ayat-ayat Alquran dalam satu surah secara berurutan.

Belajar asosiasi verbal, yaitu memberikan reaksi dalam bentuk kata-kata atau bahasa terhadap perangsang yang diterimanya. Belajar dalam bentuk ini dapat diterapkan dalam proses pembelajaran melalui metode diskusi atas materi yang banyak berhubungan dengan kehidupan anak atau yang sering dijumpai anak dalam lingkungan sekitarnya.

Belajar membedakan hal majemuk, yaitu memberikan reaksi yang berbeda terhadap perangsang yang hampir sama sifatnya. Dalam pembelajaran Pendidikan Agama Islam, bentuk perbuatan belajar ini dapat ditunjukkan dalam materi-materi yang kontra, seperti pahala dan dosa, surga dan neraka, perbuatan baik dan buruk, dunia dan akhirat, dan sebagainya.

Belajar konsep, yaitu menempatkan objek menjadi satu klasifikasi tertentu. Bentuk perbuatan belajar ini dapat ditunjukkan oleh siswa dalam membedakan perbuatan yang terpuji dengan perbuatan yang tercela, atau materi lain yang sama sifatnya dengan materi di atas.

Belajar kaidah atau belajar prinsip, yaitu menghubung-hubungkan beberapa konsep. Dalam pembelajaran akhlak misalnya, tolong menolong, jujur, adil, berbaik sangka, mengendalikan hawa nafsu, dan sebagainya, merupakan serangkian konsep yang dapat diklasifikasikan sebagai akhlak yang terpuji. 
Belajar memecahkan masalah, yaitu menggabungkan beberapa kaidah atau prinsip untuk memecahkan persoalan. Bentuk perbuatan belajar ini dapat ditunjukkan dalam mendiskusikan masalah-masalah yang berhubungan dengan materi pembelajaran yang lebih luas seperti materi ibadah yang dihubungkan dengan akhlak.

Ditinjau dari segi hasil, bentuk perbuatan belajar dibedakan atas; (1) belajar kemahiran intelektual, (2) belajar informasi verbal, (3) belajar mengatur kegiatan intelektual, (4) belajar sikap, dan (5) belajar keterampilan motorik. ${ }^{11}$ Bentuk perbuatan belajar, baik dilihat dari segi proses maupun dilihat dari segi hasil, ditunjukkan dengan tiga aspek hasil belajar, yaitu: aspek kognitif, aspek afektif, dan aspek psikomotorik.

Untuk menentukan tercapainya tujuan pendidikan dan pangajaran, perlu dilakukan usaha atau tindakan penilaian agar dapat memberikan pertimbangan harga atau nilai berdasarkan kriteria tertentu. Jadi, proses penilaian untuk menggambarkan prestasi yang dicapai seseorang dengan kriteria yang ditetapkan itulah yang disebut hasil belaja. Belajar merupakan suatu rangkaian antara proses dan hasil. Karena itu, hasil belajar siswa dapat ditunjukkan dalam suatu proses pembelajaran. Proses dan hasil belajar tersebut hanya dapat dipahami secara mendalam melalui kajian tentang makna belajar itu sendiri.

Tingkat prestasi belajar yang dicapai oleh siswa di sekolah tidak tumbuh dan berkembang begitu saja, akan tetapi merupakan suatu hasil proses interaksi dari berbagai faktor yang mempengaruhinya. Faktor-faktor yang mempengaruhi hasil belajar dapat bersifat eksternal dan internal. Faktor eksternal yaitu keadaan di luar diri siswa yang meliputi kondisi sekolah, kondisi keluarga, dan masyarakat. Sedangkan faktor internal yaitu keadaan yang berasal dari dalam diri siswa meliputi keadaan fisik dan keadaan psikologis termasuk kelemahan fisik dan psikis. ${ }^{12}$

Prestasi belajar merupakan suatu ukuran berhasil atau tidaknya seseorang dalam proses pembelajaran. Setiap proses pembelajaran selalu menghendaki agar tujuan belajar dapat tercapai. Sebagaimana yang diungkapkan oleh Sardiman AM, bahwa pembelajaran sebagai suatu proses antara belajar dan mengajar akan senantiasa merupakan proses kegiatan interaksi antara dua unsur manusiawi, yakni siswa sebagai pihak yang belajar dan guru sebagai pihak yang mengajar, dengan siswa sebagai subjek pokoknya. ${ }^{13}$

Prestasi belajar adalah ukuran berhasil atau tidaknya siswa dalam proses pembelajaran, berarti bahwa siswa harus menunjukkan kemampuan-kemampuan yang dimilikinya setelah menerima pengalaman dari proses pembelajaran. Jadi, prestasi belajar berarti tingkat penguasaan bahan pelajaran siswa dalam mata pelajaran setelah mendapat pengalaman belajar dalam proses pembelajaran dalam kurun waktu tertentu setelah memperoleh hasil tes.

Dalam proses interaksi antara siswa dengan guru, dibutuhkan komponen-komponen pendukung seperti adanya tujuan yang ingin dicapai, bahan atau pesan yang menjadi isi interaksi, pelajar yang aktif mengalami, guru yang melaksanakan, metode untuk mencapai tujuan, situasi yang memungkinkan proses pembelajaran berjalan dengan baik, serta adanya penilaian terhadap hasil belajar. ${ }^{14}$ 
Tujuan pembelajaran yang dimaksudkan adalah hasil atau prestasi yang maksimal dari siswa atau hasil evaluasi selama dalam proses pembelajaran dalam menjalankan peranannya sebagai seorang pelajar yang menempuh pendidikan pada jenjang tertentu, dengan harapan apa yang telah didapatkan selama proses pembelajaran berlangsung dapat membawa perubahan, baik terhadap dirinya, terhadap lingkungan keluarga, maupun lingkungan masyarakat yang berada di sekitarnya.

Untuk dapat mengetahui seberapa besar tingkat prestasi keberhasilan siswa dalam menguasai materi pelajaran yang telah dipelajari, diperlukan alat ukur. Alat ukur yang bisa digunakan adalah tes dan evaluasi. Hasil pengukuran dengan menggunakan tes merupakan salah satu indikator keberhasilan peserta didik yang didapat dalam usaha belajarnya.

Evaluasi hasil mengajar merupakan suatu kegitan yang dilakukan guna memberikan informasi secara berkesinambungan dan menyeluruh tentang proses dan hasil belajar yang telah dicapai oleh siswa. Untuk itu, evaluasi sangat dibutuhkan guna mengetahui berhasil atau tidaknya siswa dalam melakukan proses pembelajaran yang diterimanya dari guru.

Penilaian pada dasarnya bertujuan untuk mengetahui prestasi belajar siswa dan hasil mengajar guru. Penilaian tersebut merupakan informasi belajar atau hasil mengajar berupa kompetensi dasar yang dikuasai dan yang belum dikuasai oleh siswa, dan yang terpenting adalah hasil belajar siswa dapat digunakan untuk memotivasi siswa dalam belajar dan untuk perbaikan serta peningkatan kualitas pembelajaran oleh guru.

Prestasi belajar merupakan kemampuan yang dimiliki siswa setelah mengikuti proses pendidikan, dicerminkan antara lain dengan kualitas yang diperoleh siswa pada mata pelajaran yang telah dipelajari di sekolah. Oleh karena itu, prestasi belajar penekanannya pada hasil belajar yang dicapai dari suatu kegiatan atau aktivitas belajar. Dengan kata lain, prestasi belajar merupakan suatu hasil pendidikan yang diperoleh siswa setelah melewati proses pendidikan dalam jangka waktu tertentu.

Sebagai kesimpulan, bahwa belajar dan pembelajaran merupakan suatu proses yang melibatkan dua unsur manusiawi, yaitu guru sebagai pengajar dan siswa sebagai pelajar. Hal ini untuk mencapai prestasi belajar berupa kemampuan yang diperoleh siswa setelah melakukan proses belajar baik dalam bidang studi tertentu maupun dalam suatu cakupan kurikulum sekolah dengan menggunakan tes standar sebagai alat ukur untuk mengetahui adanya perubahan dalam aspek kecakapan, tingkah laku, dan keterampilan yang dimiliki oleh siswa yang bersangkutan.

\section{PENERAPAN FUNGSI-FUNGSI MANAJEMEN DALAM PEMBELAJARAN}

Pembelajaran yang dinyatakan sebagai proses interaksi peserta didik dengan pendidik dan sumber belajar lain dalam suatu lingkungan belajar, berlangsung dalam suatu proses interaksi. Interaksi tersebut bersifat edukatif yang melibatkan peserta didik dan pendidik sehingga guru sebagai sentral figur memegang peranan penting dalam merencanakan, mengorganisasikan, mengarahkan, dan mengendalikan proses pembelajaran di sekolah. 
Optimalisasi peran guru sebagai perencana, organisator, pengarah, dan pengendali proses pembelajaran memposisikan guru sebagai manajer pembelajaran (learning manager) dalam menciptakan iklim belajar yang memungkinkan siswa dapat belajar secara nyaman. ${ }^{15}$ Melalui penerapan manajemen pembelajaran yang baik, guru dapat menjaga kelas agar tetap kondusif untuk terjadinya proses belajar bagi seluruh siswa.

\section{Penerapan Fungsi Perencanaan dalam Pembelajaran}

Pencapaian tujuan merupakan kunci dalam segenap kegiatan manajerial dengan melakukan tindakan-tindakan yang terukur dalam menetapkan dan memelihara, serta mengendalikan kondisi lingkungan yang responsif sehingga dapat memberi sumbangan secara ekonomis, psikologis, sosial, politis, dan teknis. ${ }^{16}$

Substansi yang menjadi garapan manajemen pendidikan sebagai proses atau disebut juga fungsi manajemen adalah perencanaan, pengorganisasian, pengarahan, dan pengendalian. ${ }^{17}$ Aplikasi konsep manajemen dalam kegiatan pembelajaran tersebut mengisyaratkan bahwa manajemen pembelajaran merupakan usaha dan tindakan kepala sekolah sebagai manajer instruksional di sekolah, serta usaha dan tindakan guru sebagai manajer pembelajaran di kelas yang dilakukan sedemikian rupa untuk memperoleh hasil dalam rangka mencapai tujuan program sekolah dan program pembelajaran.

Efektivitas penerapan fungsi perencanaan dalam kegiatan pembelajaran diindikasikan dengan aplikasi prinsip-prinsip perencanaan pembelajaran tentang (1) menetapkan apa yang hendak dilakukan oleh guru, kapan dan bagaimana melakukannya dalam implementasi pembelajaran, (2) membatasi sasaran atas dasar tujuan instruksional khusus dan menetapkan pelaksanaan kerja untuk mencapai hasil yang maksimal melalui proses penentuan target pembelajaran, (3) mengembangkan alternatifalternatif yang sesuai dengan strategi pembelajaran, (4) mengumpulkan dan menganalisis informasi yang penting untuk mendukung kegiatan pembelajaran, (5) mempersiapkan dan mengkomunikasikan rencana-rencana dan keputusan-keputusan yang berkaitan dengan pembelajaran kepada pihak-pihak yang berkepentingan. ${ }^{18}$

Mengacu pada implementasi fungsi perencanaan dalam kegiatan pembelajaran tersebut, sehingga dikembangkan sejumlah indikator penelitian tentang perencanaan pembelajaran yang mencakup penyusunan kegiatan pembelajaran, penetapan dan pembatasan tujuan pembelajaran, pengembangan strategi pembelajaran, pengumpulan data dan informasi pendukung pembelajaran, dan pengkomunikasian rencanarencana pembelajaran tersebut kepada pihak terkait.

Bentuk perencanaan pembelajaran dimaksud, diukur dengan penyusunan Recana Pelaksanaan Pembelajaran (RPP) dinyatakan dengan sejumlah komponen, yaitu tujuan pembelajaran, materi ajar, metode pengajaran, sumber belajar, dan penilaian hasil belajar. ${ }^{19}$ Melalui perencanaan pembelajaran yang baik, guru dapat mempersiapkan segala sesuatu yang dibutuhkan siswa dalam belajar.

\section{Penerapan Fungsi Pengorganisasian dalam Pembelajaran}

Selain fungsi perencanaan, terdapat pula fungsi pengorganisasian dalam kegiatan pembelajaran yang dimaksudkan untuk menentukan pelaksana tugas dengan jelas 
kepada setiap personil sekolah sesuai bidang, wewenang, mata ajaran, dan tanggung jawabnya. Dengan kejelasan tugas dan tanggung jawab masing-masing unsur dan komponen pembelajaran sehingga kegiatan pembelajaran baik proses maupun kualitas yang dipersyaratkan dapat berlangsung sesuai dengan yang direncanakan.

Mengenai penerapan fungsi pengorganisasian dalam kegiatan pembelajaran, ditunjukkan dengan sejumlah indikator, yaitu (1) menyediakan fasilitas, perlengkapan, dan personil yang diperlukan untuk menyusun kerangka yang efisien dalam melaksanakan rencana-rencana melalui suatu proses penetapan pelaksanaan pembelajaran yang diperlukan untuk menyelesaikannya, (2) pengelompokan komponen pembelajaran dalam struktur sekolah secara teratur, (3) membentuk struktur wewenang dan mekanisme koordinasi pembelajaran, (4) merumuskan dan menetapkan metode dan prosedur pembelajaran, serta (5) memilih, mengadakan latihan, dan pendidikan dalam upaya pengembangan jabatan guru yang dilengkapi dengan sumber-sumber lain yang diperlukan. ${ }^{20}$

Penerapan fungsi pengorganisasian dalam manajemen pembelajaran sebagaimana yang ditunjukkan dengan sejumlah indikator di atas, telah dikembangkan sebagai tolak ukur tentang efektivitas pelaksanaan fungsi pengorganisasian dalam kegiatan pembelajaran.

\section{Penerapan Fungsi Penggerakan dalam Pembelajaran}

Fungsi manajemen pembelajaran lainnya adalah penggerakan. Penerapan fungsi penggerakan dalam pembelajaran, meliputi (1) menyusun kerangka waktu dan biaya yang diperlukan baik untuk institusi maupun pembelajaran secara rinci dan jelas, (2) memprakarsai dan menampilkan kepemimpinan dalam melaksanakan rencana dan pengambilan keputusan, (3) mengeluarkan instruksi-instruksi yang spesifik ke arah pencapaian tujuan, (4) membimbing, memotivasi, dan melakukan supervisi oleh kepala sekolah terhadap guru, (5) membimbing, memotivasi, dan memberi tuntunan atau arahan yang jelas oleh guru terhadap pelayanan belajar kepada peserta didik. ${ }^{21}$

Hubungan siswa dengan guru dalam proses pembelajaran, menempatkan guru pada posisi strategis sebagai manajer pembelajaran dengan mempersiapkan segala sesuatu yang berhubungan dengan proses pembelajaran, seperti adanya tujuan yang ingin dicapai, bahan atau pesan yang menjadi isi interaksi, pelajar yang aktif mengalami, guru yang melaksanakan, metode untuk mencapai tujuan, situasi yang memungkinkan proses pembelajaran berjalan dengan baik, serta adanya penilaian terhadap hasil belajar. ${ }^{22}$ Komponen tersebut termasuk juga cara guru memanejemen proses pembelajaran yang berlangsung sehingga tidak membosankan bagi siswa dalam kegiatan pembelajaran. Dengan demikian, hal itu akan mampu mewujudkan berhasilnya tujuan pembelajaran itu sendiri.

Penggerakan sebagai fungsi manajemen diterapkan oleh kepala sekolah bersama guru dalam pembelajaran agar siswa melakukan aktivitas belajar untuk mencapai tujuan pembelajaran yang telah direncanakan. Sehubungan dengan itu, peran kepala sekolah memegang peranan penting untuk menggerakkan para guru dalam mengoptimalkan fungsinya sebagai manajer di dalam kelas. 


\section{Penerapan Fungsi Pengawasan dalam Pembelajaran}

Pengawasan dalam konteks pembelajaran dilakukan oleh kepala sekolah terhadap kegiatan pembelajaran pada seluruh kelas, termasuk mengawasi pihak-pihak terkait sehubungan dengan pemberian pelayanan kebutuhan pembelajaran secara sungguh-sungguh. Untuk keperluan pengawasan ini, guru mengumpulkan, menganalisis, dan mengevaluasi informasi kegiatan belajar, serta memanfaatkannya untuk mengendalikan pembelajaran sehingga tercapai tujuan belajar yang telah direncanakan.

Penerapan fungsi pengawasan dalam kegiatan pembelajaran, diimplikasikan dengan sejumlah indikator, yaitu (1) mengevaluasi pelaksanaan kegiatan dibanding dengan rencana pembelajaran, (2) melaporkan penyimpangan untuk tindakan koreksi dan merumuskan tindakan koreksi, menyusun standar-standar pembelajaran dan sasaran-sasaran, (3) menilai pekerjaan dan melakukan tindakan koreksi terhadap penyimpangan-penyimpangan, baik institusional satuan pendidikan maupun proses pembelajaran. ${ }^{23}$

Adapun penerapan fungsi pengawasan dalam kegiatan pembelajaran, didasarkan pada tanggung jawab yang di dalamnya terkandung norma-norma etika, sosial, dan scientific sebagai suatu kesanggupan untuk menjalankan tugas dan kewajiban yang dipikulkan kepadanya dengan sebaik-baiknya. Dengan demikian, maka kegiatan pembelajaran yang dipertanggungjawabkan itu dapat diterima orang lain dan mengandung kebenaran yang bersifat umum. ${ }^{24}$ Manajemen yang diterapkan guru dalam proses pembelajaran, apabila diterima baik oleh siswa, maka akan berpengaruh terhadap keberhasilan belajar siswa.

\section{SIMPULAN}

Penerapan fungsi-fungsi manajemen dalam pembelajaran dimaksudkan sebagai optimalisasi peran guru dalam meningkatkan prestasi belajar siswa. Prestasi belajar berarti bahwa siswa harus menunjukkan kemampuan-kemampuan yang dimilikinya setelah menerima pengalaman dari proses pembelajaran. Karena itu, tingkat penguasaan bahan pelajaran siswa dalam mata pelajaran setelah mendapat pengalaman belajar dalam proses pembelajaran dalam kurun waktu tertentu setelah memperoleh hasil tes.

Tujuan pembelajaran yang dimaksudkan adalah hasil atau prestasi yang maksimal dari siswa atau hasil evaluasi selama dalam proses pembelajaran dalam menjalankan peranannya sebagai seorang pelajar. Ia menempuh pendidikan pada jenjang tertentu dengan harapan apa yang telah didapatkan selama proses pembelajaran berlangsung dapat membawa perubahan, baik terhadap dirinya, terhadap lingkungan keluarga, maupun dengan lingkungan masyarakat yang berada di sekitarnya.

Penerapan manajemen dalam kegiatan pembelajaran tersebut mengisyaratkan bahwa manajemen pembelajaran merupakan usaha dan tindakan kepala sekolah sebagai manajer instruksional di sekolah, serta usaha dan tindakan guru sebagai manajer pembelajaran di kelas yang dilakukan sedemikian rupa untuk memperoleh hasil dalam rangka mencapai tujuan program sekolah dan program pembelajaran. Sebagai 
manejer dalam kelas tentu saja mempunyai peran penting dalam terlaksananya pembelajaran yang sukses sehingga berpengaruh terhadap keberhasilan belajar siswa.

\section{CATATAN AKHIR:}

1. George R. Terry, Guide to Management, Diterjemahkan oleh J. Smith, Prinsip-prinsip Manajemen, cet. 6, Jakarta: PT. Bumi Aksara, 2000, h. 9.

2. Ibid.

3. Mochtar Effendy, Manajemen: Suatu Pendekatan Berdasarkan Ajaran Islam, cet. 2, Jakarta: Bhratara, 1996, h. 31.

4. M. Amien Rais, Al-Islam dan IPTEK 1, cet. 1, Jakarta: PT. Raja Grafindo Persada, 1998, h. 41.

5. Republik Indonesia, Undang-undang Republik Indonesia Nomor 20 Tahun 2003 Tentang Sistem Pendidikan Nasional, Jakarta: BP. Panca Usaha, 2003, h. 6.

6. Sardiman AM; Interaksi dan Motivasi Belajar Mengajar, cet. 16, Jakarta: PT. Raja Grafindo Persada, 2008, h. 14.

7. Noehi Nasution, dkk., Materi Pokok Psikologi Pendidikan, Jakarta: Direktorat Jenderal Pembinaan Kelembagaan Agama Islam Departemen Agama Republik Indonesia dan Universitas Terbuka, 1991, h. 34.

8. Slameto, Belajar dan Faktor-faktor yang Mempengaruhinya, cet. 3, Jakarta: PT. Rineka Cipta, 1995, h. 2.

9. Tim Penyusun Direktorat Jenderal Pembinaan Kelembagaan Agama Islam/Direktorat Pembinaan Pendidikan Agama Islam pada Sekolah Umum, Metodologi Pendidikan Agama Islam, Jakarta: Direktorat Jenderal Pembinaan Kelembagaan Agama Islam Departemen Agama RI; 2001), h. 25.

10. Nana Sudjana, Dasar-dasar Proses Belajar Mengajar, cet. 3, Bandung: Sinar Baru Algensindo, 1989, h. 46.

11. Ibid; h. 49.

12. Dalyono, Psokologi Pendidikan, cet. I, Jakarta: PT. Rineka Cipta, 1996, h. 55.

13. Sardiman AM; loc. cit.

14. Ibid; h. 13.

15. George R. Terry, loc. cit.

16. Wina Sanjaya, Perencanaan dan Desain Sistem Pembelajaran, cet. I, Jakarta: Kencana, 2008, h. 283.

17. Husaini Usman, Manajemen: Teori, Praktik, dan Riset Pendidikan, cet. 1, Jakarta: PT. Bumi Aksara, 2006, h. 10.

18. Syaiful Sagala. Konsep dan Makna Pembelajaran, cet. 8; Bandung: Alfabeta, 2010), h. 143.

19. Ibid., h. 144.

20. Wina Sanjaya, op. cit., h. 60.

21. M. Ngalim Purwanto, Administrasi dan Supervisi Pendidikan, cet. 2, Bandung: Remadja Karya, 1988, h. 81.

22. Syaiful Sagala, op. cit.,, h. 13.

23. Ibid; h. 146.

24. Ibid; h. 145.

\section{DAFTAR PUSTAKA:}

AM., Sardiman, Interaksi dan Motivasi Belajar Mengajar, cet. 16, Jakarta: PT. Raja Grafindo Persada, 2008. 
Dalyono, Psokologi Pendidikan, cet. I, Jakarta: PT. Rineka Cipta, 1996.

Effendy, Mochtar, Manajemen: Suatu Pendekatan Berdasarkan Ajaran Islam, cet. 2, Jakarta: Bhratara, 1996.

Nasution, Noehi, dkk., Materi Pokok Psikologi Pendidikan, Jakarta: Direktorat Jenderal Pembinaan Kelembagaan Agama Islam Departemen Agama Republik Indonesia dan Universitas Terbuka, 1991.

Purwanto, M. Ngalim, Administrasi dan Supervisi Pendidikan, cet. 2, Bandung: Remadja Karya, 1988.

Rais, M. Amien, Al-Islam dan IPTEK 1, cet. 1, Jakarta: PT. Raja Grafindo Persada, 1998.

Republik Indonesia, Undang-undang Republik Indonesia Nomor 20 Tahun 2003 Tentang Sistem Pendidikan Nasional, Jakarta: BP. Panca Usaha, 2003.

Sagala, Syaiful, Konsep dan Makna Pembelajaran, cet. 8, Bandung: Alfabeta, 2010.

Sanjaya, Wina, Perencanaan dan Desain Sistem Pembelajaran, cet. I, Jakarta: Kencana, 2008.

Slameto, Belajar dan Faktor-faktor yang Mempengaruhinya, cet. 3, Jakarta: PT. Rineka Cipta, 1995.

Sudjana, Nana, Dasar-dasar Proses Belajar Mengajar, cet. 3, Bandung: Sinar Baru Algensindo, 1989.

Terry, George R., Guide to Management, Diterjemahkan oleh J. Smith, Prinsip-prinsip Manajemen, cet. 6, Jakarta: PT. Bumi Aksara, 2000.

Tim Penyusun Direktorat Jenderal Pembinaan Kelembagaan Agama Islam/Direktorat Pembinaan Pendidikan Agama Islam pada Sekolah Umum, Metodologi Pendidikan Agama Islam, Jakarta: Direktorat Jenderal Pembinaan Kelembagaan Agama Islam Departemen Agama RI, 2001.

Usman, Husaini, Manajemen: Teori, Praktik, dan Riset Pendidikan, cet. 1, Jakarta: PT. Bumi Aksara, 2006. 